\title{
Trends of homicides in Galle-Sri Lanka
}

Rathnaweera RHAI*

Department of Forensic Medicine, Faculty of Medicine, Karapitiya, Galle, Sri Lanka

*Corresponding author: Tel: 0094-772969060. E-mail address:

ajithrathnaweera@yahoo.com

MLJSL.Vol 3. No 1. March. pp 16-21

\section{Abstract}

\section{Introduction}

The intentional killing of a human being by another is the ultimate crime. Its indisputable physical consequences manifested in the form of a dead body also makes it the most categorical and calculable.

\section{Objective}

The objective was to document epidemiological, socio-economic and postmortem data on homicides reported to the Teaching hospital Karapitiya, from $1^{\text {st }}$ of January 2011 to $31^{\text {st }}$ of December 2011 and to compare with the findings of previous studies done in other parts of the country.

\section{Materials and Methods}

All the potential homicide cases referred to the Teaching hospital, Karapitiya during the study period were retrospectively analyzed.

\section{Results}

Out of the 40 homicides, 34 were men (85\%). The majority (62.5\%) of those was in the 21-40 age group. Most cases were $(20 \%)$ reported from the Meetiyagoda police area. Sharp force was the commonest method (45\%) used, followed by firearm (30\%) and blunt force (25\%). Knife was the commonest sharp weapon used (50\%) and chest was the commonest site injured(88\%). In fire arm deaths, commonest type of weapon was the rifled fire arm (84\%) and chest remains the commonest site of injury. In blunt force trauma, head and face remains the frequently targeted site (100\%).

\section{Conclusions}

Majority were young married males belonging to lower socio-economic group. In sharp force trauma and firearm homicides, the commonest target was chest whereas in blunt force trauma, the commonest target was the head. Sharp cutting weapons have become more popular. Meetiyagoda, Karandeniya and Elpitiya have more homicides.

Key words: homicides, Sharp cutting weapons, knife, chest

\section{Introduction}

The intentional killing of a human being by another is the ultimate crime. Its indisputable physical consequences manifested in the form of a dead body also make it the most categorical and calculable. 
Homicide can be defined as any killing of one human being by another. The term applies to all such killings, whether criminal or not.

According to the penal code of Sri Lanka [1], homicide can be,

1. Culpable homicide (section 293)

2. Murder (section 294)

3. Culpable homicide not amounting to murder (294 exceptions)

Culpable homicide is defined as "whoever causes death by doing an act with the intention of causing death, or with the intention of causing such bodily injury as is likely to cause death, or with the knowledge that he is likely by such act to cause death, commits the offence of culpable homicide" [1].

The difference between murder and culpable homicide not amounting to murder, is only a difference in the degree of knowledge and intention. A higher degree of knowledge and intention is required to establish a charge of murder. Even a charge of murder can be reduced to one of culpable homicide not amounting to murder under exceptional circumstances (Exceptions 1 to 5 in section 294 of the penal code) [1].

Globally, the total number of annual deaths estimated by UNODC to be homicides in 2010 was 468,000 . More than a third ( 36 per cent) of those are estimated to have occurred in Africa, 31 per cent in the Americas, 27 per cent in Asia, 5 per cent in Europe and $1 \%$ in Oceania [2]. Disparities not only exist in how homicide is distributed around the world but also between its typologies, which show varying degrees of prevalence in different regions. Among the different contexts in which homicide can occur, including homicide related to robbery, gangs, fights, sexual motives, and familial disputes, two forms in depth-organized crime/gang related homicide, and intimate partner/family related homicide stands out [2].

The wave of crimes has been rapidly increasing in Sri Lanka as a key social problem [3]. Crimes are the major criterion of determining development in each country[2]. Homicides are increased at present rapidly than earlier because of the complexity and the competition of the society [3].

\section{Objective}

The objective of this retrospective study was to analyze epidemiological, socio-economic and postmortem data on homicides reported to the Teaching hospital Karapitiya, from $1^{\text {st }}$ of January 2011 to $31^{\text {st }}$ of December 2011 and to compare with the findings of previous studies done in other parts of the country.

\section{Materials and Methods}

All the potential homicide cases referred to the Teaching hospital, Karapitiya during the oneyear period from $1^{\text {st }}$ of January 2011 to $31^{\text {st }}$ of December 2011, were retrospectively studied. A pre-coded data collection form was developed and ages, sex, marital and occupational status, method and reasons for homicide, and injury patterns were analyzed.

\section{Results}

During the study period, 1121 deaths were subjected to postmortem examination at the Teaching hospital Karapitiya. Out of that 704 (62\%) were natural, 267 (24\%) were accidental, $110(10 \%)$ were suicidal and 40 (4\%) were homicidal.

Out of the 40 homicides, 34 were men (85\%) and 6 were women (15\%).

The majority (62.5\%) of those who were murdered was in the 21-40 age group, indicating that most of the murders occurred among the young and middle-aged population (Table 1). Youngest victim was a sixteen year old boy and the oldest victim was an eighty four year old male.

Of the 28 males, four (16\%) were single and 24 $(84 \%)$ were married. Of the six females, two (33\%) were single and four (67\%) were married. Ten males $(25 \%)$ were under the influence of alcohol at the time of homicide. 
Occupational status of victims showed that $40 \%$ were unemployed and $47.5 \%$ were working as unskilled or semiskilled labourers. Three professionals $(7.5 \%)$ were murdered in this population. Twenty percent of homicides were reported during the month of April (Table 2).

Table 1: Age group of victims

\begin{tabular}{lll}
\hline Age group (years) & No & $\%$ \\
\hline $00-10$ & 00 & $00 \%$ \\
$11-20$ & 01 & $2.5 \%$ \\
$21-30$ & 11 & $27.5 \%$ \\
$31-40$ & 14 & $35 \%$ \\
$41-50$ & 01 & $2.5 \%$ \\
$51-60$ & 10 & $25 \%$ \\
$61-70$ & 02 & $5 \%$ \\
$71-80$ & 00 & $00 \%$ \\
$81-90$ & 01 & $2.5 \%$ \\
\hline
\end{tabular}

Table 2: Month of the year

\begin{tabular}{lll}
\hline Month & No & $\%$ \\
\hline January & 02 & $5 \%$ \\
February & 03 & $7.5 \%$ \\
March & 03 & $7.5 \%$ \\
April & 08 & $20 \%$ \\
May & 06 & $15 \%$ \\
June & 00 & $00 \%$ \\
July & 02 & $05 \%$ \\
August & 01 & $2.5 \%$ \\
September & 01 & $2.5 \%$ \\
October & 07 & $17.5 \%$ \\
November & 04 & $10 \%$ \\
December & 03 & $7.5 \%$ \\
\hline
\end{tabular}

Most of the homicide cases were (20\%) reported from the Meetiyagoda police area followed by Karandeniya (15\%) and Elpitya(15\%).

Analysis of the method of homicide showed that sharp force was the commonest method ( $n=18 ; 45 \%)$, followed by fire arm $(n=13 ; 30 \%)$ and blunt force ( $n=9 ; 25 \%)$.

Most of the homicides (45\%) were reported during $5.00 \mathrm{pm}$ and $7.00 \mathrm{pm}$. Time was not known in $22.5 \%$ of cases (Table 3 ).
The assailant was known in $32(80 \%)$ of the cases. All assailant unknown $(20 \%)$ cases were firearm deaths (Table 4).

Table 3: Time of the day

\begin{tabular}{llllll}
\hline $\begin{array}{l}\text { Time } \\
\text { (am) }\end{array}$ & No & $\%$ & $\begin{array}{l}\text { Time } \\
\text { (pm) }\end{array}$ & No & $\%$ \\
\hline $\begin{array}{l}12.00- \\
1.00\end{array}$ & 01 & $2.5 \%$ & $\begin{array}{l}12.00- \\
1.00\end{array}$ & 00 & $00 \%$ \\
$1.00-2.00$ & 00 & $00 \%$ & $1.00-2.00$ & 01 & $2.5 \%$ \\
$2.00-3.00$ & 00 & $00 \%$ & $2.00-3.00$ & 00 & $00 \%$ \\
$3.00-4.00$ & 00 & $00 \%$ & $3.00-4.00$ & 01 & $2.5 \%$ \\
$4.00-5.00$ & 00 & $00 \%$ & $4.00-5.00$ & 00 & $00 \%$ \\
$5.00-6.00$ & 00 & $00 \%$ & $5.00-6.00$ & 11 & $27.5 \%$ \\
$6.00-7.00$ & 00 & $00 \%$ & $6.00-7.00$ & 07 & $17.5 \%$ \\
$7.00-8.00$ & 00 & $00 \%$ & $7.00-8.00$ & 01 & $2.5 \%$ \\
$8.00-9.00$ & 01 & $2.5 \%$ & $8.00-9.00$ & 02 & $05 \%$ \\
$9.00-$ & 00 & $00 \%$ & $9.00-$ & 02 & $05 \%$ \\
10.00 & & & 10.00 & & \\
$10.00-$ & 01 & $2.5 \%$ & $10.00-$ & 02 & $05 \%$ \\
11.00 & & & 11.00 & & \\
$11.00-$ & 00 & $00 \%$ & $11.00-$ & 01 & $2.5 \%$ \\
12.00 & & & 12.00 & & \\
\hline
\end{tabular}

Table 4: Assailant

\begin{tabular}{cll}
\hline Assailant & No & $\%$ \\
\hline Known-Known person & 23 & $57.5 \%$ \\
Friend & 05 & $12.5 \%$ \\
Relation & 04 & $10 \%$ \\
Unknown & 08 & $20 \%$ \\
\hline
\end{tabular}

According to the evidence given at the inquest, the reason for homicide was unknown in $40 \%$ of cases (Table 5 ) and in $22.5 \%$ of cases it was due to financial matters.

Table 5: Reason given at the inquest for committing homicide

\begin{tabular}{lll}
\hline Reason given & No & $\%$ \\
\hline Reason not known & 16 & $40 \%$ \\
Financial matters & 09 & $22.5 \%$ \\
Family disputes & 08 & $20 \%$ \\
Related to women & 07 & $17.5 \%$ \\
\hline
\end{tabular}


When considering sharp force trauma homicides, knife was the commonest method used (50\%), followed by sword (44\%) and axe (6\%). Twenty three percent of the victims had a single stab injury where as $45 \%$ had $2-5$ stabs (Table 06).

Table 06: No of stabs

\begin{tabular}{lll}
\hline No of stabs & No & $\%$ \\
\hline 1 & 4 & $23 \%$ \\
$2-5$ & 8 & $45 \%$ \\
$6-10$ & 5 & $27 \%$ \\
$>10$ & 1 & $05 \%$ \\
\hline
\end{tabular}

Fifty percent had cut injuries only where as $44 \%$ had stabs only. $6 \%$ had both cuts and stabs.

Chest injuries were the commonest (88\%) followed by upper limb injuries (Table 07 ).

Table 07: Location of the incised wounds

\begin{tabular}{lll}
\hline Site & No & $\%$ \\
\hline Chest & 16 & $88 \%$ \\
Abdomen & 08 & $44 \%$ \\
Head and face & 11 & $61 \%$ \\
Neck & 07 & $38 \%$ \\
Upper arm & 08 & $44 \%$ \\
Fore arm \& hand & 12 & $66 \%$ \\
Thigh & 02 & $11 \%$ \\
Leg \& foot & 10 & $55 \%$ \\
Perineum & 00 & $00 \%$ \\
\hline
\end{tabular}

Lungs found to be the commonest organ to be injured (55\%) followed by neck vessels (44\%) and heart (39\%) (Table 08).

When considering firearm deaths, the type of weapon was a rifled fire arm in $84 \%$ of cases and it was a shot gun in $16 \%$ of cases.

Single firearm injury present in 03 (23\%) of cases and 2-5 entries were present in 05(45\%) of cases. There were 6-10 injuries in $04(27 \%)$ and more than 10 injuries were seen in 01 (05\%).

Lungs were the frequently injured organ (77\%) followed by heart (53\%) and brain (38\%)
When considering the entry and exit wounds, chest remains the commonest site followed by head and face and abdomen (Table 09).

Table 08: Internal organ injuries (incised wounds)

\begin{tabular}{lll}
\hline Internal organ & No & $\%$ \\
\hline Trachea & 02 & $11 \%$ \\
Heart & 07 & $39 \%$ \\
Lung & 10 & $55 \%$ \\
Neck vessels & 08 & $44 \%$ \\
Bowel & 03 & $16 \%$ \\
Pancreas & 02 & $11 \%$ \\
Kidney & 01 & $06 \%$ \\
Liver & 03 & $16 \%$ \\
Brain & 03 & $16 \%$ \\
\hline
\end{tabular}

When considering blunt force trauma homicides, wooden clubs were the frequently used weapon (66\%) followed by iron bar (23\%). All the victims were subjected to 2-5 blows. Head and face remains the frequently targeted site $(100 \%)$ followed by upper limbs $(44 \%)$ (Table 10)

Brain was the commonly injured internal organ (88\%) following blunt force trauma (Table 11).

Table 09: Entry Vs Exit fire arm wounds

\begin{tabular}{|c|c|c|c|c|c|}
\hline $\begin{array}{ll}\text { Site } & \text { of } \\
\text { entry } & \\
\end{array}$ & No & $\%$ & $\begin{array}{l}\text { Site of } \\
\text { exit }\end{array}$ & No & $\%$ \\
\hline $\begin{array}{l}\text { Head and } \\
\text { face }\end{array}$ & 06 & $46 \%$ & $\begin{array}{l}\text { Head and } \\
\text { face }\end{array}$ & 06 & $46 \%$ \\
\hline Neck & 01 & $07 \%$ & Neck & 01 & $07 \%$ \\
\hline Chest & 14 & $107 \%$ & Chest & 09 & $69 \%$ \\
\hline Abdomen & 06 & $46 \%$ & Abdomen & 05 & $38 \%$ \\
\hline $\begin{array}{l}\text { Upper } \\
\text { arm }\end{array}$ & 01 & $07 \%$ & $\begin{array}{l}\text { Upper } \\
\text { arm }\end{array}$ & 01 & $07 \%$ \\
\hline $\begin{array}{l}\text { Fore arm } \\
\& \text { palm }\end{array}$ & 04 & $30 \%$ & $\begin{array}{l}\text { Fore arm } \\
\& \text { palm }\end{array}$ & 04 & $30 \%$ \\
\hline Thigh & 03 & $23 \%$ & Thigh & 03 & $23 \%$ \\
\hline $\begin{array}{l}\text { Leg \& } \\
\text { foot }\end{array}$ & 00 & $00 \%$ & $\begin{array}{l}\text { Leg } \\
\text { foot }\end{array}$ & 00 & $00 \%$ \\
\hline Perineum & 00 & $00 \%$ & Perineum & 00 & $00 \%$ \\
\hline
\end{tabular}


Table 10 Site for blunt force trauma

\begin{tabular}{lll}
\hline Site & No & $\%$ \\
\hline Head and face & 09 & $100 \%$ \\
Chest & 02 & $22 \%$ \\
Upper arm & 01 & $11 \%$ \\
Fore arm \& hand & 03 & $33 \%$ \\
Leg \& foot & 02 & $22 \%$ \\
\hline
\end{tabular}

Table 11 Internal organ injuries

\begin{tabular}{lll}
\hline Internal organ & No & $\%$ \\
\hline Brain & 08 & $88 \%$ \\
Lung & 01 & $11 \%$ \\
Upper limb fractures & 02 & $22 \%$ \\
\hline
\end{tabular}

\section{Discussion}

There are many reasons why people kill each other and multiple driving forces often interact when they do, but homicide levels and trends indicate that the link between homicide and development is one of the clearest [4]. Higher levels of homicide are associated with low human and economic development. The largest shares of homicides occur in countries with low levels of human development, and countries with high levels of income inequality are afflicted by homicide rates almost four times higher than more equal societies [5].

In this study, male to female ratio was around $5: 1$. Similar findings were observed in a study done at the Department of Forensic Medicine, Faculty of Medicine Galle in 2008 [6] The majority $(62.5 \%)$ of those who were murdered was in the 21-40 age group, indicating that most of the murders occurred among the young and middle-aged population. Similar findings were observed in the past[6]. Occupational status of victims showed that $40 \%$ were unemployed and $47.5 \%$ were working as unskilled or semiskilled labourers. Three professionals (7.5\%) were murdered in this population. Twenty percent of homicides were reported during the month of April. Similar findings were observed in the past [6]. Reason for this development needs to be studied further. Most of the homicide cases were (20\%) reported from the Meetiyagoda police area. Karandeniya and Elpitiya police areas also had significant number of cases (15\% each). Most of the homicides (45\%) were reported during $5.00 \mathrm{pm}$ and $7.00 \mathrm{pm}$. Similar findings were observed in the past[6]. This could be the time where most of the people return home from their working place. They may well be under the influence of alcohol as well.

Analysis of the method of homicide showed that sharp force was the commonest method ( $n=18 ; 45 \%)$, followed by firearm $(n=13 ; 30 \%)$ and blunt force $(n=9 ; 25 \%)$. In a study done in the year 2006 and 2008 [6, 7], firearm was the commonest method used for murder. This dramatic change could be due to the fact that once the north-east war is over, lesser number of firearms are available in the society. The assailant was known in $32(80 \%)$ of the cases. All assailant unknown (20\%) cases were firearm deaths and they were supposed to be contract killings. According to the evidence given at the inquest, the reason for homicide was unknown in $40 \%$ of cases and $22.5 \%$ of cases it was due to financial matters. Similar findings were observed in the past[6].

When considering sharp force trauma homicides, knife was the commonest method used (50\%), followed by sword (44\%) and axe (6\%). In the 2008 study also, knife was the commonest sharp force weapon used. Twenty three percent of the victims had a single stab injury where as $45 \%$ had $2-5$ stabs indicating the intention of the assailant. Chest injuries were the commonest (88\%) followed by upper limb injuries. Limb injuries were more likely to be defense injuries. Lungs were the commonest organ to be injured (55\%) followed by neck vessels (44\%) and heart (39\%). In the 2008 study[7], head was the commonest target with $36 \%$.

When considering firearm deaths, the type of weapon was a rifled fire arm in $84 \%$ of cases and it was a shot gun only in $16 \%$ of cases. Single firearm injury was present in $23 \%$ of cases and 2-5 entries were present in $45 \%$ of 
cases. Average number of shots present in a victim was 5.7 in a similar study done in 20052006 [8]. When considering the entry and exit wounds, chest remains the commonest site followed by head, face and abdomen. Lungs were the frequently injured organ (77\%) followed by heart (53\%) and brain (38\%). This suggests the target was usually chest rather than head. In previous studies, it was noted that head was the usual target [6].

Head and face remains the frequently targeted site $(100 \%)$ in blunt force trauma homicides followed by upper limbs (44\%). Brain was the commonly injured internal organ (88\%). All the victims were subjected to $2-5$ blows.

\section{Conclusions}

Majority were young married males belonging to lower socio-economic group. The distribution of age, sex, marital status, occupation, time of the incident and the month in which the most number of homicide cases were reported remains similar to previous studies. In sharp force trauma and firearm homicides, the commonest target was the chest where as in blunt force trauma, the commonest target was the head. There is a definite change in the method used for homicides in the war era and post-war era. Sharp cutting weapons have become more popular. Swords are being used as often as the knives. Firearms are being used in cases where the assailant is unidentified. Meetiyagoda, Karandeniya and Elpitiya have more homicides. Reasons for this high rate of crimes in certain police areas needsto be studied further. More Homicides were reported in April than in any other month. All these new developments need to be studied further to reduce the number of murders in Sri Lanka.

\section{References}

1. Legislative enactment. Penal code of Sri Lanka

2. Global study on homicide 2011; trends, context, data: United nations office on drugs and crimes: pp 01-15.

3. Jayathunga N.S. A Sociological Study of the Homicide in Sri Lanka: A Case Study in Rathnapura Secretariat Division; Sabaragamuwa University Journal. Volume 9 Number 1; December 2010, pp 45-55.

4. Davis J. Medicolegal death investigation. Dolinak D, Matshes E, Lew E: Forensic pathology: Principles and practice. San Diego, CA: Elsevier; 2005. Pp 232-256.

5. Marrilyn J, Christopher M. Homicide and suicide in Yorkshire and the Humber; Am j Forensic Med Pathol 2010; 31(1):58-63

6. Vidanapathirana M. An analysis of postmortem data of culpable homicides reffered to the department of Forensic Medicine, Faculty of Medicine, Galle during two time periods (1995-1999 and 2004-2008): The college of Forensic pathologists of Sri Lanka, $7^{\text {th }}$ annual academic sessions.

7. Edirisingha P.A.S., Kitulwatte I.G.D. Extreme violence - Homicide; an analysis of 265 cases from the offices of JMO Colombo and Ragama - A Study from Sri Lanka. The journal of Forensic and Legal Medicine 2009;11(1): 363-365.

8. Edirisinghe PA, Kitulwatte IG. Homicidal firearm injuries: a study from Sri Lanka. Forensic Sci Med Pathol.2010;6(2):93-8. 